\title{
The On-Demand Work (Mis)classification Judgments in Italy. An Overview Marco Biasi*
}

1. Introduction. 2. The relevant legal framework. 3. The factual background. 4. The common understanding of Italian Courts on the (lack of) employment subordination in the "ondemand work" cases. 5. The (ir)relevance of article 2 Decreto Legislativo No. 81/2015: the blurry boundary between being "organized" and being "directed" by a Platform. 6. Concluding remarks: dum Romae consulitur, Augusta Taurinorum expugnatur?

Abstract
After a brief recap of the Italian legal framework in matter of employment subordination, the
A. analyzes the three Judgments of the Italian Courts concerning the classification of on-demand
work. The A. underlines the complexity of the classification of the new forms of work through
the traditional criteria of interpretations, but he also criticizes the initiative of the Italian
Legislator, which, passing article 2 Decreto Legislativo No. $81 / 2015$, traced a doubtful boundary
between the direction of work (still the essence of employment subordination) and the
organization of other's work (a feature which should lead to the application of employment
standards without losing the nature of independent contractor). Ultimately, the A. contends that
the burden of finding an adequate response to the social needs of on-demand workers cannot
be placed (entirely) upon the Courts, since it is a matter of policy (action) at large. Accordingly,
he weights and eventually endorses the regulatory trajectory of conferring upon - certainly
vulnerable, regardless of their classification as employees or independent contractors - on-
demand workers a bundle of selected protections, through a "ad hoc" statute and/or via
collective bargaining.
Keywords: Gig Economy; On-demand work; Worker Classification; Italian Judgments;
Regulatory perspectives.

\section{Introduction.}

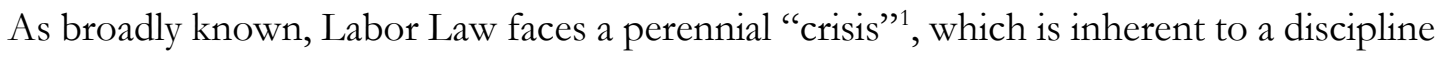
that continuously evolves in the attempt to "trail" (i.e. to adapt to) the ongoing changes of the methods of production ${ }^{2}$.

\footnotetext{
* Researcher of Labour Law, Università degli Studi di Milano. This article has been submitted to a double-blind peer review process.

${ }^{1}$ Davidov G., A Purposive Approach to Labour Law, Oxford University Press, 2016, 1.

${ }^{2}$ Weiss M., Re-Inventing Labour Law?, in Davidov G., Langille B. (eds.), The Idea of Labour Law, Oxford University Press, 2011, 43.
} 
As occurred in the past shift "from widgets to digits", the recent development of the platform economy, which led to the further shift "from digits to platform", has severely challenged the existing (i.e. traditional) categories and institutions of Labor Law ${ }^{5}$.

Considering how the decision on the employment status still determines if one is entitled to a significant package of rights or, conversely, to a much lower protection (or to no protection at all $)^{6}$, it is not surprising that the scholarly debate has been mainly focused on the classification of the new forms of work ${ }^{7}$, generally referred to as "gig work" .

The latter definition - or, better, label" - comprises both "on-demand work" and "crowdwork", but the two groups have to be kept rigorously separated ${ }^{10}$. In the former, traditional working activities - such as food delivery and passenger transportation - are coordinated via smartphone apps, whilst the latter consists in a series of - normally repetitive - tasks assigned through online platforms (such as Amazon Turk and Task Rabbit) that reach out to an indefinite number of individuals (i.e. a crowd) through the internet ${ }^{11}$.

Italian Courts have dealt with the claims brought by on-demand workers and in particular by app-driven food delivery riders, whereas crowd-work has been this far relegated to its "virtual" - or even "invisible"12 - dimension".

After a brief recap of both the relevant law provisions and the factual background, the first part of the article will provide an account of the three Italian judgments on the classification of on-demand workers.

Notably, worker classification was the only (due) scope of the judicial scrutiny. In the words of Tribunale di Torino ${ }^{14}$, "the appropriateness of the agreed remuneration, the risk of labor exploitation and the other complex issues concerning the gig-economy" could not be

\footnotetext{
3 Stone K.V.W., From Widgets to Digits. Employment Regulation for the Changing Workplace, Cambridge University Press, 2004, passim.

${ }^{4}$ Biasi M., Review, Ales E., Deinert O., Kenner J. (eds.), Core and Contingent Work in the European Union. A Comparative Analysis, in European Journal of Social Security, 19, 4, 2017, 363. See extensively Signorini, E., Il diritto del lavoro nell'economia digitale, Giappichelli, 2018.

${ }^{5}$ Dau-Schmidt K. G., The Impact of Emerging Information Technologies on the Employment Relationship: New Gigs for Labor and Employment Law, in The University of Chicago Legal Forum, 2017, 63; Cherry M.A., Beyond Misclassification: The Digital Transformation of Work, in Comparative Labor Law and Policy Journal, 37, 3, 2016, 581; Lobel O., The Law of the Platform, in Minnesota Law Review, 101, 2016, 87.

${ }^{6}$ Davidov G., Freedland, M., Kountouris, N., The Subjects of Labor Law: Employees and Other Workers, in Finkin, M.W., Mundlak G. (eds.), Comparative Labor Law. Research Handbooks in Comparative Law Series, Elgar, 2015, 115. ${ }^{7}$ Hendrickx F., Regulating new ways of working: From the new 'wow' to the new 'bow', in European Labour Law Journal, 9 , 2, 2018, 125.

${ }^{8}$ Cunningham-Parmeter K., From Amazon to Uber: Defining Employment in the Modern Economy, in Boston University Law Review, 96, 2016, 1673; Izvanariu P. A., Matters Settled But Not Resolved: Worker Misclassification in the Rideshare Sector, in De Paul Law Review, 66, 1, 2016, 133; in the Italian literature, see Menegatti E., On-Demand Workers by Application: autonomia o subordinazione?, in Zilio Grandi G., Biasi M. (eds.), Commentario Breve allo Statuto del Lavoro Autonomo e del Lavoro Agile, Cedam, 2018, 94; Voza R., Il lavoro e le piattaforme digitali: the same old story?, in WP C.S.D.L.E. "Massimo D'Antona".IT, 36, 2017.

${ }^{9}$ De Stefano V., Introduction: Crowdsourcing, the Gig-Economy, and the Law, in Comparative Labor Law \& Policy Journal, 37, 2016, 461.

${ }^{10}$ De Stefano V., The rise of the «just-in-time workforce»: On-Demand Work, Crowdwork and Labour Protection in the «GigEconomy", in ILO Paper Series, 71, 2016, 1.

11 Prassl J., Humans as a Service. The Promise and Perils of Work in the Gig Economy, Oxford University Press, 2018, passim. For another taxonomy of "gig-work", see Faioli M., Il lavoro nella Gig-Economy, I quaderni del CNEL, 2018, 16.

${ }^{12}$ Spinelli C., Tecnologie digitali e lavoro agile, Cacucci, 2018, 24.

13 Tullini P., Quali regole per il lavoratore-utente del web? Scambio economico e tutele, in Tullini P. (ed.), Web e lavoro. Profili evolutivi e di tutela, Giappichelli, 2017, 154.

14 Tribunale di Torino 7 maggio 2018, in Argomenti di Diritto del Lavoro, 4/5, 2018, 1220.
} 
examined by the Court. In fact, these latter issues are matters of policy and not of law (interpretation), so the Italian Courts correctly abstained from addressing them. Conversely, the outcome of the rulings certainly marks a regulatory gap that will be discussed in the final part of the essay. Thereby, the A. will scrutinize the solutions that are currently lying (rectius, piled) on the tables of the policy makers, that ultimately seem to possibly lean towards the idea of conferring upon - certainly vulnerable, regardless of their classification as "nonemployees" - on-demand workers a bundle of selected protections.

\section{The relevant legal framework.}

Pursuant to article 2094 of the Italian Civil Code, the employee is "a person who commits, in return for a remuneration, to cooperating in the undertaking...in service and under the direction of the employer".

Instead, under a contract for services "a self-employed worker performs work or services in exchange for an income, mainly through her own effort and in the lack of any subordination vis-à-vis the principal" (article 2222 of the Italian Civil Code) ${ }^{15}$.

According to settled case law, the essential feature of employment subordination (also) in Italy is the power of direction, which somehow mirrors the common law "control test" basically, the employer exercises managerial and disciplinary powers, telling the employee what and mostly how to do something ${ }^{17}$.

Although the classification of the working performance does not strictly hinge upon the nature or type of the working activity ${ }^{18}$, the traditional test was questioned - in Italy like almost everywhere - by the mentioned shift from an industry to a service economy which took place ahead of the recent digital transformation.

A major legal challenge was brought by Legge No. 533/1973 which, passing an amendment to article 409 of Italian Civil Procedure Code, allowed the (Self-Employed) workers who "collaborate[d] with a principal under a continuous, coordinated and mainly personal relationship" to claim their (basically, contract-based) rights before the Labor Courts (in place of the ordinary Civil Courts).

The express acknowledgment of the circumstance that Self-Employed workers could be coordinating with (or coordinated by) their clients for a prolonged period of time ("continuity"), so that their obligation vis-à-vis seemed to shift from "result" to "means", somehow contributed to the blurring of the distinction between employment and selfemployment.

\footnotetext{
${ }^{15}$ See Ales E. The Concept of "Employee": The Position in Italy", in Waas B., Heerma van Voss G. (eds.), Restatement of Labour Law in Europe, I, The Concept of Employee, Hart, 2017, 351; Cataudella M.C., Types of Worker and Employment Contract, in Carinci F., Menegatti E. (eds.), Labour Law and Industrial Relations in Italy, Wolters Kluwer, 2015, 1; Nogler L., The Concept of "Subordination" in European and Comparative Law, Università degli Studi di Trento, 2009.

${ }^{16}$ Veneziani B., The Evolution of the Contract of Employment, in Hepple, B. (ed.), The Making of Labour Law in Europe, Hart, 1986, 63-68.

${ }_{17}$ The method of working is the key: Deakin S., Assessing the Italian Jobs Act: A Comment on Del Conte and Gramano, in Comparative Labor Law \& Policy Journal, 39, 2018, 610

${ }^{18}$ Cass. 8 febbraio 2010, n. 2728, in Guida Dir., 2010, 13, 68.
} 
Moreover, in the opinion of many, the effect was a spillover from (fully protected) employment towards (almost unprotected and often non-genuine) self-employment ${ }^{19}$.

Not by chance, the subsequent "Biagi Reform" (Decreto Legislativo No. 276/2003) granted the "cococo" (i.e. the "coordinated, continuous collaborations") workers, under the label of "Project-Based Contract", a limited set of rights (such as the right to the suspension of contractual obligations in case of maternity, parental, sickness), along with social security contributions $^{20}$. The rights of "Project-Based" workers were further expanded by 2012 "Fornero Reform" (Legge No. 92/2012), which stipulated that the fees due to "ProjectBased" workers could not be inferior to the wage rate of the "corresponding" employees. The provision at stake was extremely relevant, as it prevented the potential recourse to selfemployment for merely economic (and not organizational) purposes and, above all, it finally addressed the wage issue, which (slightly) later became arguably the core of the demands of gig-workers ${ }^{21}$.

However, Renzi Government "Jobs Act" Reform of 2015 repealed the whole discipline of (and thus displaced the protections granted to) the "Project-based work"22.

Contextually, the highly disputed article 2 Decreto Legislativo No. 81/2015 dictated that "the whole discipline of employment subordination applies to self-employment relationships where the working activity is continuously carried out personally by the worker and the client organizes the working process, also with reference to the time and the place of work".

A part of scholars advanced the interpretation of the mentioned provision according to which "the gray area between subordinate and employees and independent contractors has been dramatically reduced"23: in their opinion, the scope of application of employment law protection was extended towards certain areas of self-employment that, despite their weakness in the market, did not fit into employment subordination.

Others contended that article 2 Decreto Legislativo No. 81/2015 affected the same notion of employee and it had to lead to a more careful scrutiny of the features of the organization of both the time and the place of the working activity.

A third view denied that article 2 Decreto Legislativo No. 81/2015 could have any innovative effect, since a worker whose performance was organized (in its time and place... and not only) could already be classified as an employee by the Italian Courts.

Notably, a previous judicial trend suggested to replace the idea of "eterodirezione" with the concept of "subordinazione attenuata" ("mitigate subordination") in two cases ${ }^{24}$ :

a) a worker performing very simple activities;

\footnotetext{
${ }^{19}$ Cherry M.A., Aloisi A., "Dependent Contractors" in the Gig Economy: a Comparative Approach, in American University Law Review, 66, 3, 2017, 635.

${ }^{20}$ Biasi M., The Effect of the Global Crisis on the Labor Market: Report on Italy, in Comparative Labor Law \& Policy Journal, 35, 2014, 385.

${ }^{21}$ Berg J., Income Security in the On-Demand Economy: Findings and Policy Lessons from a Survey of Crowdworkers, in Conditions of Work and Employment Series, ILO Working Paper n. 74/2016.

22 Only with Legge No. 81/2017, the Legislator bestowed upon genuine self-employed workers a limited set of labour protections, such as i) the guarantee of payments in commercial transactions; ii) the ban on abusive clauses, iii) the prohibition of the abuse of economic dependency; iv) further social protections; v) the right to have access to labor market institutions.

${ }^{23}$ Del Conte M., Gramano E., Looking to the Other Side of the Bench: The New Legal Status of Independent Contractors, under the Italian Legal System, in Comparative Labor Law \& Policy Journal, 39, 2018, 582.

${ }^{24}$ Cass 11 ottobre 2017, n. 2384; Cass. 8 aprile 2015, n. 7024; Cass. 28 marzo 2003, n. 4770; Cass. 13 aprile 2012, n. 5886; Cass. 7 ottobre 2013, n. 22785; Cass 2 aprile 2009, n. 8068; Cass. 6 settembre 2007, n. 18692.
} 
b) a worker performing very sophisticated and knowledge-intensive activities.

In these situations, the absence of the employer's power of closed supervision and detailed direction did not preclude the finding in favor of an employment contract, since complementary factors were also taken into account, such as:

i) the continuity of the relationship;

ii) the modality of payment;

iii) the risk allocation;

iv) the ownership of the means of production;

Yet, according to a different line of thought, which was confirmed by a recent ruling of the Constitutional Court ${ }^{25}$, employment subordination still required that the employer exercised a closed supervision and a detailed direction over the worker, which was thus subject to the "managerial, disciplinary and directive power" of the former ${ }^{26}$.

Notwithstanding this binary divide in the interpretation of Italian Courts, it is now generally agreed that economic dependency is not at stake in the classification judgments.

This emerged clearly from a famous case involving the classification of the working activity carried out by "pony express" (i.e. parcel delivery bikers), which could be considered the ancestors of the today's app-driven riders ${ }^{27}$.

In fact, an early judgment by Pretura di Milano ruled that the concrete meaning of article 2094 of the Italian Civil Code was rooted in the continuous development of socioeconomic reality, so that the judge had the power to find the fair and reasonable solution to the individual case, having also regard on the socio/economic condition of the parties ${ }^{28}$.

However, the decision was overturned on appeal ${ }^{29}$ and never upheld thereafter. On the contrary, the Italian Supreme Court confirmed that, pursuant to article 2094 of Italian Civil Code, subordinate employment occurred only if the company exercised a strict control over the working time and the manners of a working performance ${ }^{30}$.

In a nutshell, economic dependency might matter in a policy perspective (see infra), but, at present, it does not play any role in the legal distinction between employment and selfemployment, which is still rooted in the power of direction and/or on the integration of the worker in the organization of the firm ${ }^{31}$.

\footnotetext{
${ }^{25}$ Corte Costituzionale 15 aprile 2015, n. 76. According to a previous ruling of the Italian Constitutional Court (Corte Costituzionale 12 febbraio 1996, n. 30), employment subordination was featured by a "double alienation": i.e. the alienation of the worker from the product of the work and the alienation of the worker from the organization of production. See Pietrogiovanni V., Redefining the Boundaries of Labour Law: Is "Double Aliennes" a Useful Concept for Classifying Employees in Times of Fractal Work?, in Blackham A., Kullmann M., Zbyszewska A., Theorising Labour Law in a Changing World - Towards Inclusive Labour Law, Hart, 2019, 55.

${ }^{26}$ Cass. 4 marzo 2015, n. 4346; Cass. 13 dicembre 2010, n. 25150; Cass. 22 novembre 2010, n. 23032; Cass. 22 dicembre 2009, n. 26986; Cassazione 9 aprile 2018, n. 8687; Cass. 4 marzo 2015, n. 4346; Cass. 13 dicembre 2010, n. 25150; Cass. 22 novembre 2010, n. 23032; Cass. 22 dicembre 2009, n. 26986.

${ }^{27}$ Klooger v. Foodora Australia Pty Ltd 16 ${ }^{\text {th }}$ november 2018, (2018) FWC 6836.

28 Pretura di Milano 20 giugno 1986. see also Pretura di Milano 7 ottobre 1988; Pretura di Torino 12 febbraio 1996; Pretura Penale di Torino 28 marzo 1990; Cassazione, Sezione III Penale, 21 marzo 1989.

${ }^{29}$ Tribunale di Milano 10 ottobre 1987. see also Cassazione 10 luglio 1991, n. 7608; Pretura di Napoli 21 agosto 1991; Tribunale di Napoli 11 dicembre 1989.

${ }^{30}$ Cassazione 20 gennaio 2011, n. 1238. See also Cassazione 25 gennaio 1993, n. 811; Tribunale di Torino 25 maggio 1998; Tribunale di Milano 15 marzo 1991; Pretura di Roma 26 aprile 1990.

31 Razzolini O., The Need To Go Beyond The Contract: "Economic" and "Bureaucratic" Dependence in Personal Work Relations, in Comparative Labor Law \& Policy Journal, 31, 1, 2010, 267.
} 


\section{The factual background.}

Italian Gig-economy cases concerned "on-demand” food delivery riders.

The agreements between the workers and the platform companies showcased some relevant divergences, as to the obligations of the parties, but they clearly converged in the exclusion of employment subordination ${ }^{32}$.

As emerged from the judicial discovery, riders attended a preliminary interview where middle managers clarified that a bicycle and a smartphone with Internet access were required for the working activity and they requested a deposit for safety devices such as helmets, fluorescent jackets with the company logo, and a lunchbox ${ }^{33}$.

The workers entered into a "collaborazione coordinata e continuativa" (co.co.co.) agreement with the Platform (i.e. the Company which managed the Platform) ${ }^{34}$, according to which "the worker shall be free to apply or not apply for a specific delivery depending on her or his personal availability".

At the beginning of every week, the platform published a list of the shifts available for the "free" application of the riders.

Once the riders applied for the sports and the shifts were assigned by the platform, the riders reached the "hotspot areas" and they logged-in via app, so that they were able to display the orders.

Once the rider accepted a request, he/she rode to the restaurant, picked up the food and delivered the latter to the client of the platform.

Riders were paid by the Platform a flat fee - varying over time, up to $5.60 €$ (gross) - per delivery.

\section{The common understanding of Italian Courts on the (lack of) employment subordination in the "on-demand work" cases.}

In all three "gig-economy" judgments the employment status of the plaintiffs was ruled out by the Italian Courts on similar - although not identical - grounds.

According to Tribunale di Torino 7 maggio $2018^{35}$, the freedom enjoyed by the riders in deciding if and when to apply for a delivery (so, basically, to work) was at odds with employment subordination, since it deprived the platform of the power to organize and direct the working performance ${ }^{36}$.

\footnotetext{
32 Biasi M., Dai pony express ai riders di Foodora. L'attualità del binomio subordinazione-autonomia (e del relativo metodo di indagine) quale alternativa all'affannosa ricerca di inedite categorie, in Zilio Grandi G., Biasi M., Commentario Breve allo Statuto del Lavoro Autonomo e del Lavoro Agile, Cedam, 2018, 67.

33 Aloisi A., "With great power comes virtual freedom": A Review of the First Italian Case Holding that (Food-delivery) Platform Workers are not Employees, in Comparative Labor Law \& Policy Journal, Dispatch No. 13/2018.

${ }^{34}$ Lunardon F., Le reti d'impresa e le piattaforme digitali della sharing economy, in Argomenti di Diritto del Lavoro, 2, 2018, 375.

35 Tribunale di Torino 7 maggio 2018, cit.

${ }^{36}$ Lawson v. Grubhub Inc, 8th February 2018, U.S. District Court for the Northern District of California, No. 3:15-cv-05128; Razak v. Uber Technologies Inc, 11 th April 2018, U.S. District Court for the Eastern District of Pennsylvania, No. 2:16-cv-00573; Kaseris v Rasier Pacific V.O.F [2017] FWC) 21 ${ }^{\text {st }}$ December 2017; Conseil de Prud'hommes de Paris 29 janvier 2018; Juzgado de lo Social de Madrid 11 enero 2019. Contra Cour de Cassation 28 novembre 2018, TakeEastEasy; Cour d'Appel de Paris 10 janvier 2019; Juzgado de lo Social Madrid 11
} 
Moreover, workers were not «subjected to managerial, organizational and disciplinary powers, resulting from specific orders given as well as to a constant surveillance and monitoring over the performance execution $\rangle^{37}$. In fact, riders were (apparently) free to choose their route from the restaurant to the client of the platform, even though their position was visible via app ${ }^{38}$.

Similarly, in the opinion of Tribunale di Milano 10 settembre $2018^{39}$, the freedom enjoyed by the riders in deciding if and when to work was not consistent with an employment relationship.

The ruling by Tribunale di Torino on the (lack of) employment subordination was upheld by Corte d'Appello di Torino 4 febbraio $2019^{40}$, which additionally observed that the limited duration of riders" commitment on a weekly basis ("no more than twelve hours per week on average") was at odds with employment subordination. Indeed, this statement by Corte d'Appello di Torino was rather surprising, given the existence of (subordinate) part-time employment and "job-on-call" in the Italian legal framework ${ }^{41}$ and, more broadly, the irrelevance of the "average duration" of the working activity in the classification process, which, as already remarked, still hinges on the Italian version of the "control test" ${ }^{42}$.

\section{The (ir)relevance of article 2 Decreto Legislativo No. 81/2015: the blurry boundary between being "organized" and being "directed" by the Platform.}

According to Tribunale di Torino 7 maggio 2018, despite the clear intention of the policymakers law-maker to broaden the scope of employment subordination, article 2 Decreto Legislativo No. 81/2015 could not have any effect on Italian employment law and, consequently, on the classification of the claimants.

In the Court's view, the requirements to qualify for the protection as "organized" worker were stricter than the "simple" exercise of the power of direction by the employer, considering how in the modern workplace many employees - such as managers and supervisors $^{43}$ - enjoyed a significant degree of freedom in matter of time and place of work ${ }^{44}$.

febrero 2019; Juzgado de lo Social Gijón 20 febrero 2019. For an updated account of the Gig-economy judgments in the different jurisdictions, See https://ignasibeltran.com/2018/12/09/employment-status-ofplatform-workers-national-courts-decisions-overview-australia-brazil-chile-france-italy-united-kingdomunited-states-spain/.

37 Tribunal Regional do Trabalho da 3a Região, 9a Turma, Minas Gerais, 27 maio 2017; Juzgado de lo Social Madrid 3 septiembre 2018, n. 284/2018. Contra Vara do Trabalho de Belo Horizonte 14 fevereiro 2017; Trib. Valencia 1 junio 2018, n. 244/2018.

${ }^{38}$ Juzgado de lo Social Barcelona 21 mayo 2019.

39 Tribunale di Milano 10 settembre 2018, in ilgiuslavorista.it, 20 settembre 2018.

${ }^{40}$ Corte d'Appello di Torino 4 febbraio 2019, in Argomenti di Diritto del Lavoro, 3, 2019, 144.

${ }^{41}$ See Novella M., Il rider non è lavoratore subordinato, ma è tutelato come se lo fosse, in Labour \& Law Issues, 1, 2019, 95.

${ }^{42}$ Del Frate M., Le collaborazioni etero-organizzate alla prova della giurisprudenza di merito, in Diritto delle Relaztioni Industriali, 2019, forthcoming.

43 Biasi M., Brevi riflessioni sulla categoria dirigeñiale all'indomani del Jobs Act, in Diritto delle Relarioni Industriali, 3, 2016, 760 .

44 Tosi P., L'art. 2, comma 1, d.lgs. n. 81/2015: una norma apparente?, in Arg. Dir. Lav., 6, 2015, 1127. 
In other words, the provision seems to bestow upon workers who could have already been classified as employees the rights of the...employees ${ }^{45}$.

However, Corte d'Appello di Torino reversed the ruling of Tribunale di Torino in matter, holding that, through article 2 Decreto Legislativo No. 81/2015, the Italian legislator introduced a «tertium genus» (i.e. an intermediate category) between employment and selfemployment ${ }^{46}$, with the aim of granting a special protection to the developing new forms of work.

In the legal scheme of article 2 Decreto Legislativo No. 81/2015, a working activity was "functionally inserted in (not merely coordinated by) the client's business" the case of riders, where, despite the fact that the latter were not employees, the platform had the power to define the shifts and the starting and final locations of the delivery tasks.

Accordingly, employment protections had to be applied, pursuant to article 2 Decreto Legislativo No. 81/2015, to the "organized" riders as such, with the exception of dismissal protection, since their contracts had a "natural" expiry date (the fulfillment of the task) and thus they could not claim against a dismissal that formally never occurred ${ }^{48}$.

The reasoning of Corte d'Appello di Torino was not fully convincing on different grounds.

One might argue that it is hard to "organize" the time and place of a person's working activity without "directing" the latter", considering how "the employee's working performance gets organized and planned by the employment in furtherance of the primary interest of the latter" ${ }^{30}$.

Accordingly, once Corte d'Appello di Torino ascertained the "functional integration of the worker in the organization of the firm", the consequence could have been the ruling in favor of employment subordination pursuant to article 2094 of the Italian Civil Code instead of the application of employment protections according to article 2 Decreto Legislativo No. $81 / 2015^{51}$.

Not by chance, due to the complete integration of the working activity in the organization of the firm a recent Australian decision classified the claimants (Foodora riders) as employees $^{52}$.

\footnotetext{
45 Albi P., Il lavoro mediante piattaforme digitali tra autonomia e subordinazione, in Labor, 2, 2019, 128.

${ }^{46}$ See also Tribunale di Roma 6 maggio 2019, in Argomenti di Diritto del Lavoro, 5, 2019, forthcoming.

47 Perulli A., The Notion of "Employee" in Need of Redefinition, EU Commission, Directorate-General for Employment, Social Affairs and Inclusion, European Centre of Expertise (ECE), April 2017, 8, holding that article 2 Decreto Legislativo No. 81/2015 "may be usefully applied to digital platform workers that...do not necessarily offer their services under a directional power in traditional sense, but they are anyway under the organization of the platform".

48 See Lazzari C., Alla ricerca di tutele per i gig-workers, fra supplenza giurisprudenziale, regolazione sociale e tentativi di normazione eteronoma, in Argomenti di Diritto del Lavoro, 3, 2019, 518; Tullini P., Le collaborazioni etero-organizzate dei riders: quali tutele applicabili?, in Lavoro Diritti Europa, 1, 2019, 6.

${ }^{49}$ Santoro Passarelli G., Sul nomen juris e le possibili tutele del rapporto di lavoro dei riders, in giustiziacivile.com, 30 aprile 2019. See, in general, Carinci F., La subordinazione rivisitata alla luce dell'ultima legislazione: dalla "subordinazione" alle "subordinazioni"?, in Argomenti di Diritto del Lavoro, 4/5, 2018, 968.

${ }^{50}$ Mancini G.F., La responsabilità contrattuale del prestatore di lavoro, Giuffrè, 1957, 23. Persiani M., Contratto di lavoro e organizzazione, Cedam, 1966.

${ }^{51}$ De Luca Tamajo R., La Sentenza della Corte d'Appello Torino sul caso Foodora. Ai confini tra autonomia e subordinazione, in Lavoro Diritti Europa, 1, 2019, 7-8.

${ }^{52}$ Klooger v. Foodora Australia Pty Ltd 16 ${ }^{\text {th }}$ November 2018, (2018) FWC 6836.
} 
The argument in word might also provide further evidence of the spillover effect of intermediate categories $^{53}$, capable of influencing the construction of employment subordination rather than (or along with) the court strategy of the plaintiff ${ }^{54}$, despite the fact that the "organized worker" under article 2 Decreto Legislativo No. 81/2015 is not stricto sensu a "tertium genus"

It is interesting to note that Tribunale di Milano, which also construed article 2 Decreto Legislativo No. 81/2015 as a mechanism of extension of employment rights to those selfemployed workers that are organized by their clients ${ }^{56}$, excluded that the applicants were "organized by the client with regards to the time and place, since they enjoyed to freedom to decide when and where to work".

Significantly, Tribunale di Milano deployed the same argument to rule out the employment status of the claimants and to exclude the application to the latter of the employment protections pursuant to article 2 Decreto Legislativo No. 81/2015.

This seems a further sign of the complexity to trace a doubtful boundary between the direction of work (the essence of "traditional" employment subordination) and the organization of other's work (a feature which should lead, pursuant to article 2 Decreto Legislativo No. 81/2015, to the application of employment standards to a subgroup of selfemployed workers).

\section{Concluding remarks: dum Romae consulitur, Augusta Taurinorum expugnatur?}

In the wake of the early gig-economy judgments, it is clear that, in Italy (but arguably not only), the complex and assorted issues concerning the gig-economy could not be resolved through the mere (mis)classification cases ${ }^{57}$.

This does mean that the classification of the relevant workers lost its primary importance ${ }^{58}$. On the contrary, notwithstanding the difficulties to apply the traditional

\footnotetext{
${ }^{53}$ Notably, in Britain, where the third category of the "worker" enjoys some of the rights conferred upon employees, such as minimum wage, holiday, working time limitations (Davidov G., Who is a worker?, in Industrial Law Journal, 1, 2005, 1, 57), Uber drivers were classified as "workers" (and not employees) despite the circumstance that their services were recognized as an integral part of Uber's operations. See Uber BV v Aslam \& Ors [2018] EWCA Civ 2748; Uber B.V. and Others v Mr Y Aslam and Others, 26 October 2016, [2017] IRLR 4; Employment Appeal Tribunal, Uber_B.V._and_Others_v_Mr_Y_Aslam_and_Others, _UKEAT_0056_17_DA.

${ }^{54}$ Pietrogiovanni V., L’importanza di chiamarsi lavoratori, ossia delle corti del Regno Unito alle (p) rese con il lavoro a chiamata sulle piattaforme, in Labour \& Law Issues, 1, 2019, 64.

55 In fact, the Italian Legislator opted to extend the overall employment protection to a subgroup of (arguably) self-employed workers and not to bestow upon an isolated category between employment and self-employment a specific (i.e. ad hoc) bundle of rights: see Cherry M.A., The Cautionary Tale of the Intermediate Worker Category in Italy: A Response to Del Conte and Gramano, in Comparative Labor Law \& Policy Journal, 39, 2018, 639, and, in a policy perspective, Ales E., Protecting Work in the Digital Transformation: Rethinking the Typological Approach in the Intrinsically Triangular Relationship Perspective, in Aa.Vv., Working in Digital and Smart Organizations Legal, Economic and Organizational Perspectives on the Digitalization of Labour Relations, Palgrave, 2018, 21.

56 See also TAR Lazio 6 aprile 2018, in ilgiuslavorista, 4 luglio 2018, Tribunale di Cuneo 13 dicembre 2017, in Banca Dati DeJure.

${ }^{57}$ Dubal V. B., Winning the Battle, Losing the War?: Assessing the Impact of Misclassification Litigation on Workers in the Gig Economy, in Wisconsin Law Review, 2017, 739.

58 Ales E., Protecting Work in the Digital Transformation: Retbinking the Typological Approach in the Intrinsically Triangular Relationship Perspective, cit., 21.
} 
categories to the new forms of work ${ }^{59}$, an effort to rethink the rooted interpretation, also by means of a (very careful) recourse to the comparative method ${ }^{60}$, seems due ${ }^{61}$.

Whilst inferring that employment subordination is based on the socio/economic vulnerability of the worker would still contrast with the letter of the law, one might argue that the judicial scrutiny should have placed more weigh on the effects of the innovative rating systems ${ }^{62}$ and, in particular, on the effect of the latter on the worker's freedom to accept or not accept the single tasks ${ }^{63}$.

It goes without saying that the sophisticated algorithmic system should be at first "decoded" by software experts, whereas Italian Courts have this far relied just upon the rather swift - hearing of the platform administration managers and employees, that could possibly be completely and effectively unaware of the functioning of such delicate instruments ${ }^{64}$.

Still, as stated by the Tribunal of Amsterdam, "when contracts such as those used by platforms like Deliveroo are considered to be undesirable, then parliament should take autonomous steps" ${ }^{\prime \prime 5}$. That is to say that Case-law might certainly stimulate a statutory intervention ${ }^{66}$, but, pursuant to the well-known principle of separation of powers, the law and the policy perspectives have to be kept apart, especially in the Continental Europe Systems.

Accordingly, (only) a policy discourse might well (or, better, should) take into account the distinctive features of economic dependency and discontinuity, which mark the condition of on-demand and in general gig workers ${ }^{67}$, regardless of the legal classification of the relevant activities $^{68}$.

${ }^{59}$ Cotter v. Lyft, Inc., 60 F. Supp. 3d 1067 (N.D. Cal. 2015); O’Connor v. Uber Technologies, Inc., 82 F.Supp.3d 1133 (N.D. Cal. 2015). See Keeton, R.B., An Uber Dilemma: The Conflict Between the Seattle Rideshare Ordinance, the NLRA, and For-Hire Driver Worker Classification, in Gonzaga Law Review, 42, 2017, 207.

${ }^{60}$ Biasi M., Uno sguardo oltre confine: $i$ "nuovi lavori" della gig economy. Potenzialità e limiti della comparazione, in Labour \& Law Issues, 4, 2, 2018, 1; Papa V., Post-industriale o pre-moderno? Economia digitale e lavoratori on-demand: nuovi paradigmi organizzativi e vecchie esigenze di tutela, in Diritto delle Relazioni Industriali, 3, 2018, 729; Pacella G., Il lavoro tramite piattaforma digitale nella giurisprudenza dei Paesi di civil law, in Labour \& Law Issues, 1, 2019, 17.

${ }^{61}$ On the recent development of "ABC Test" in California and on its potential effects on the gig-economy cases, see Gould IV, W.B., Dynamex is Dynamite, but Epic Systems Is Its Foil - Chamber of Commerce: The Sleeper in the Trilogy, in Missouri Law Review, 83, 4, 2018, 1005; Sachs, B., Looks like the gig is up for Uber in California, in onlabor, may $1^{\text {st }} 2018$.

62 Schubert C., Hütt M.-T., Economy-on-demand and the fairness of algorithms, in European Labour Law Journal, 10, 1, 3.

${ }^{63}$ Bolego G., Intelligenza artificiale e regolazione delle relazioni di lavoro: prime riflessioni, in Labor, 1, 2019, 61; De Simone G., Lavoro digitale e subordinazione. prime riflessioni, in Rivista Giuridica del Lavoro, I, 1, 2019, 14; Dagnino E., People analytics: lavoro e tutele al tempo del management tramite big data, in Labour \& Law Issues, 3, 1, 2017, 1.

${ }^{64}$ Maio V., Il lavoro per le piattaforme digitali tra qualificazione del rapporto e tutele, in Argomenti di Diritto del Lavoro, 3, $2018,127$.

${ }^{65}$ Rechtbank Amsterdam 23 juli 2018, Sytze Ferwerda v. Deliveroo, 6622665 CV EXPL 18-2673.

66 According to Cavallini G., Né subordinati, né autonomi, i rider di Foodora sono collaboratori "etero-organizzati", in Sintesi, 2, 2019, 12, the judgment of Corte d'Appello di Torino provided the unions with a "chip" for the opening of a collective bargaining negotiation.

${ }^{67}$ Davidov G., The Status of Uber Drivers: A Purposive Approach, in Spanish Labour Law and Employment Relations Journal, 6, 2017, 6; Rogers B., Employment Rights in the Platform Economy: Getting Back to Basics, in Harvard Law \& Policy Review, 10, 2016, 479. Todoli-Signes A., The End of the Subordinate Worker? The On-Demand Economy, the Gig Economy, and the Need for Protection for Crowdworkers, in International Journal of Comparative Labour Law \& Industrial Relations, 33, 2, 2017, 241; In the Italian literature, see Perulli A., Lavoro e tecnica al tempo di Uber, in Rivista Giuridica del Lavoro, 2017, 2, I, 195; Loi P., Il lavoro nella gig economy nella prospettiva del rischio, in Rivista Giuridica del Lavoro, I, 2, 2017, 259;

${ }^{68}$ Treu T., Rimedi, tutele e fattispecie: riflessioni a partire dai lavoratori della Gig economy, in Lavoro e Diritto, 3-4, 2017, 367; Ferrante V., Subordinaz̧ione, dipendenza, abitualità, personalità: riflessioni e proposte per la tutela dei "nuovi” lavori, in 
Yet, in a regulatory perspective, a preliminary question concerns the choice between statutory intervention and collective bargaining.

The latter source, which has finally gained its space beyond the traditional sphere of employment subordination ${ }^{69}$, bears the burden of its natural inter partes (i.e. non general) effect, without mentioning the complexities of organizing "virtual" workers ${ }^{70}$.

These issues emerged in the experience of the "Charter of Digital Workers Rights", which was a tripartite document signed in Bologna in 2018 by the Municipality, the major Italian unions but only a few (mainly, local) platforms ${ }^{71}$. The mentioned Charter granted digital workers a bundle of rights regardless of their classification (as employees). This raised the further doubt that, in so far as it was addressing (also) the services rendered by self-employed workers, it could infringe European Competition Law ${ }^{72}$. However, since collective bargaining is enshrined by both European Union and National Law as a fundamental social right, it might be - prima facie: this knot has not been fully untangled yet - safeguarded from the potential intromissions of competition law ${ }^{73}$.

Conversely, a company-level collective agreement signed in May 2019 provided a detailed regulation of the working conditions of the riders employed by an undertaking based in Florence $^{74}$. Such a solution is surely interesting, but it does not overcome the classification dilemma, as its application hinges on the decision of the company to hire the riders with a subordinate employment contract.

As to the statutory source, anyone might probably welcome a European Union initiative that could address both the economic and the social repercussions of the platform economy, but, at least this far, the European documents have been no more than cautious or even tentative approaches ${ }^{75}$.

At the national level, the exclusive competence of State action in matter of "civil order regulation" under article 117 of the Italian Constitution should prevent a regional or a local initiative ${ }^{76}$.

Labor, 1, 2019, 32; Ciucciovino S., Le nuove questioni di regolazione del lavoro nell'industria 4.0 e nella gig economy: un problem framework per la riflessione, in Diritto delle Relazioni Industriali, 4, 2018, 1045.

69 Caruso B., I diritti dei lavoratori digitali nella prospettiva del Pilastro sociale, in WP C.S.D.L.E. "Massimo D'Antona”.INT, 146/2018.

70 Occhino A., Nuove soggettività e nuove rappresentanze del lavoro nell'economia digitale, in Labor, 1, 2019, 39; Lassandari A., La tutela collettiva del lavoro nelle piattaforme digitali: gli iniži di un percorso difficile, in Labour \& Law Issues, 4, 1, 2018, IV; Recchia G.A., Alone in the crowd? La rappresentanza e l'azione collettiva ai tempi della sharing economy, in Rivista Giuridica del Lavoro, 1, 2018, 141; Forlivesi M., Interessi collettivi e rappresentanza dei lavoratori del web, in Tullini P. (ed.), Web e lavoro. Profili evolutivi e di tutela, Giappichelli, 2017, 179.

${ }^{71}$ Martelloni F., Individuale e collettivo: quando i diritti dei lavoratori digitali corrono su due ruote, in Labour \& Law Issues, 1, 2018, 1,4 .

${ }^{72}$ CJEU - Case C-413/13, FNV Kunsten Informatie en Media v. Staat der Nederlanden, ECLI:EU:C:2014:2411.

${ }^{73}$ Biasi M., "We Will All Langh at Gilded Butterflies". The Shadow of Antitrust Law on the Collective Negotiation of Fair Fees for Self-Employed Workers, in European Labour Law Journal, 9, 4, 2018, 354.

${ }^{74}$ See https://www.lavorodirittieuropa.it/images/accordo quadro firenze 10 maggio 2019.pdf.

75 See the European Commission Communication to the European Parliament, the Council, the European Economic Social Committee and the Committee of the Regions, A European agenda for the collaborative economy, $\operatorname{COM}(2016) 356$ final of 2 June 2016: Delfino M., Work in the age of collaborative platforms between innovation and tradition, in European Labour Law Journal, 9, 4, 2018, 11346.

${ }^{76}$ Legge della Regione Lazio 12 aprile 2019, n. 4 (“Norme per la tutela e la sicurezza dei lavoratori digitali"). See Torsello L., I lavoro dei riders. L'iniziativa di legge nella Regione Lazio, in Diritti regionali. Rivista di diritto delle autonomie territoriali, 3, 2018, 2. 
Accordingly, a State-level regulation, in the wake of the French example ${ }^{77}$, seems the only feasible way.

Still, State regulation and collective bargaining law are not mutually exclusive. In fact, a statutory bundle of basic rights for on-demand workers might be effectively complemented by collective negotiations, which could take into account the specific features of the platform's sector of activity ${ }^{78}$.

This was arguably the purpose of "Riders Amendment" ("Emendamento Riders"”), a Bill which (in)formally circulated in first quarter of 2019, when the decree in matter of basic income (Decreto Legge No. 4/2019) was about to be converted into Legge No. 75/2019.

However, the Bill, which was never fully discussed in Parliament, appeared over-selective, as it addressed only the - non "organized" 79 - on-demand riders delivering food in urban context ${ }^{80}$. Those latter would have been bestowed upon primarily health and safety guarantees, but many other core protections were missing, from minimum wage to paid holidays and working time limitation, without forgetting social security and welfare benefits ${ }^{81}$.

Conclusively, a better balance between statutory and collective action might be the key to cope with the challenges raised by the on-demand economy and to overcome the traditional dualism between fully-protected employees and under-protected self-employed workers, which the Italian Legislator has not been able to effectively mitigate yet. In the meanwhile, as the legislator kept fiddling (“dum Romae consulitur"), Corte d'Appello di Torino, reversing the ruling of Tribunale di Torino, granted the claiming riders (a part of) the basic employment rights they demanded (“Augusta Taurinorum expugnatur”), thus calling the Italian Corte di Cassazione, where the case is currently pending, to a paramount Judgment in (and for) the next future.

\footnotetext{
${ }^{77}$ Loi n 2016-1088 du 8 août 2016 relative au travail, à la modernisation du dialogue social et à la sécurisation des parcours professionnels. See Bargain G., The new French labor law: Loi no. 2016-1088 du 8 aout 2016 relative au travail, à la modernisation du dialogue social et à la sécurisation des parcours professionnels, in Comparative Labor Law and Policy Journal, Dispatch n. 4/2017. See also the recent Spanish and Portuguese initiatives: Baylos Grau A., El papel de la negociación colectiva en la ley de protección de datos personales y garantía de derechos digitales en España, in Labour \& Law Issues, 1, 2019, 1; Leal Amado J., Coelho Moreira T., La legge portoghese sul trasporto passeggeri tramite piattaforma elettronica: soggetti, rapporti e presunzioni, in Labour \& Law Issues, 1, 2019, 50.

${ }^{78}$ Romagnoli U., Se l'amore per la specie fa perdere di vista il genere (a proposito del caso Foodora), in Diritti Lavori Mercati, 1, 2018, 198.

${ }^{79}$ As "organized" workers would have still been under the scope of article 2 Decreto Legislativo No. 81/2015.

${ }^{80}$ So, what about the riders who deliver beverage (not food) just outside the urban areas?.

${ }^{81}$ Voza R., Nuove sfide per il welfare: la tutela del lavoro nella gig economy, in Rivista del Diritto della Sicurezza Sociale, 4, 2018, 657; see Secunda P., Uber Retirement, 2017,

https://papers.ssrn.com/sol3/papers.cfm?abstract_id=2894566.
} 


\section{Bibliography}

Albi P., Il lavoro mediante piattaforme digitali tra autonomia e subordinazione, in Labor, 2, 2019, 125; Ales E., Protecting Work in the Digital Transformation: Rethinking the Typological Approach in the Intrinsically Triangular Relationship Perspective, in Aa.Vv., Working in Digital and Smart Organizations Legal, Economic and Organizational Perspectives on the Digitalization of Labour Relations, Palgrave, 2018, 11;

Ales E. The Concept of "Employee": The Position in Italy", in Waas B., Heerma van Voss G. (eds.), Restatement of Labour Law in Europe, I, The Concept of Employee, Hart, 2017, 351;

Aloisi A., "With great power comes virtual freedom": A Review of the First Italian Case Holding that (Food-delivery) Platform Workers are not Employees, in Comparative Labor Law \& Policy Journal, Dispatch No. 13/2018;

Bargain G., The new French labor law: Loi no. 2016-1088 du 8 aout 2016 relative au travail, à la modernisation du dialogue social et à la sécurisation des parcours professionnels, in Comparative Labor Law and Policy Journal, Dispatch No n. 4/2017.

Biasi M., Dai pony express ai riders di Foodora. L'attualità del binomio subordinazione-autonomia (e del relativo metodo di indagine) quale alternativa all'affannosa ricerca di inedite categorie, in Zilio Grandi, G., Biasi M. (eds.), Commentario Breve allo Statuto del Lavoro Autonomo e del Lavoro Agile, Cedam, 2018, 67;

Biasi M., "We Will All Langh at Gilded Butterflies". The Shadow of Antitrust Law on the Collective Negotiation of Fair Fees for Self-Employed Workers, in European Labour Law Journal, 9, 4, 2018, 354; Biasi M., Review of Edoardo Ales, Olaf Deinert, Jeff Kenner (eds.), Core and Contingent Work in the European Union. A Comparative Analysis', in European Journal of Social Security, 19, 4, 2017, 363;

Biasi M., The Effect of the Global Crisis on The Labor Market: Report on Italy, in Comparative Labor Law \& Policy Journal, 35, 2014, 371;

Bolego G., Intelligenza artificiale e regolazione delle relazioni di lavoro: prime riflessioni, in Labor, 1, 2019, 51;

Carinci F., La subordinazione rivisitata alla luce dell'ultima legislazione: dalla "subordinazione" alle "subordinazioni"?, in Argomenti di Diritto del Lavoro, 4/5, 2018, 961;

Caruso B., I diritti dei lavoratori digitali nella prospettiva del Pilastro sociale, in WP C.S.D.L.E. “Massimo D'Antona”.INT, 146/2018;

Cataudella M.C., Types of Worker and Employment Contract, in Carinci F., Menegatti E. (eds.), Labour Law and Industrial Relations in Italy, Wolters Kluwer, 2015, 1;

Cherry M.A., The Cautionary Tale of the Intermediate Worker Category in Italy: A Response to Del Conte and Gramano, in Comparative Labor Law \& Policy Journal, 39, 2018, 639;

Cherry M.A., 'Beyond Misclassification: The Digital Transformation of Work', in Comparative Labor Law \& Policy Journal, 37(3), 581;

Cherry M.A., Aloisi A., Dependent contractors in the gig economy: a comparative approach, in American University Law Review, 66, 2017, 636;

Ciucciovino S., Le nuove questioni di regolazione del lavoro nellindustria 4.0 e nella gig economy: un problem framework, per la riflessione, in Diritto delle Relazioni Industriali, 4, 2018, 1043;

Dagnino E., People analytics: lavoro e tutele al tempo del management tramite big data, in Labour \& Law Issues, 3, 1, 2017, 1; 
Dau-Schmid K.G., The Problem of 'Misclassification' or How to Define Who is an 'Employee' Under Protective Legislation in the Information Age, 2018, https:// ssrn.com/abstract=3143296;

Dau-Schmidt K.G., 'The Impact of Emerging Information Technologies on the Employment Relationship: New Gigs for Labor and Employment Law', in The University of Chicago Legal Forum, 2017, 63;

Davidov G., The Status of Uber Drivers: A Purposive Approach, in Spanish Labour Law and Employment Relations Journal, 6, 2017, 6;

Davidov G., A Purposive Approach to Labour Law, Oxford University Press, 2016;

Davidov G., Freedland, M. and Kountouris, N., The Subjects of Labor Law: "Employees" and other Workers, in Finkin, M.W., Mundlak, G. (eds.) Comparative Labor Law, Research Handbooks in Comparative Law, Edward Elgar, 2015, 115;

Deakin S., Assessing the Italian Jobs Act: A Comment on Del Conte and Gramano, in Comparative Labor Law \& Policy Journal, 39, 2018, 607;

Delfino M., Work in the age of collaborative platforms between innovation and tradition, in European Labour Law Journal, 9, 4, 2018, 346;

De Luca Tamajo R., La Sentenza della Corte d'Appello Torino sul caso Foodora. Ai confini tra autonomia e subordinazione, in Lavoro Diritti Europa, 1, 2019, 1;

De Simone G., Lavoro digitale e subordinazione. prime riflessioni, in Rivista Giuridica del Lavoro, I, 1, 2019, 3;

Dubal V.B., Winning the Battle, Losing the War?: Assessing the Impact of Misclassification Litigation on Workers in the Gig Economy, in Wisconsin Law Review, 2017, 739;

Faioli M., Il lavoro nella Gig-Economy, I quaderni del CNEL, 2018;

Ferrante, V., Subordinazione, dipendenza, abitualità, personalità: riflessioni e proposte per la tutela dei "nuovi" lavori, in Labor, 1, 2019, 23;

Forlivesi M., Interessi collettivi e rappresentanza dei lavoratori del web, in Tullini P. (ed.), Web e lavoro. Profili evolutivi e di tutela, Giappichelli, 2017, 179;

Gould IV W.B., Dynamex is Dynamite, but Epic Systems Is Its Foil - Chamber of Commerce: The Sleeper in the Trilogy, in Missouri Law Review, 83, 4, 2018, 989;

Hendrickx F., Regulating new ways of working: From the new 'wow' to the new 'bow', in European Labour Law Journal, 9, 2, 2018, 125;

Izvanariu P. A., Matters Settled But Not Resolved: Worker Misclassification in the Rideshare Sector, in De Paul Law Review, 66, 1, 2016, 133;

Keeton R.B., An Uber Dilemma: The Conflict Between the Seattle Rideshare Ordinance, the NLRA, and For-Hire Driver Worker Classification, in Gonzaga Law Review, 42, 2017, 207;

Kenner J., Uber Drivers are 'Workers' - The Expanding Scope of the 'Worker' Concept in the UK's Gig Economy, 2019, https://ssrn.com/abstract=3312226;

Lassandari A., La tutela collettiva del lavoro nelle piattaforme digitali: gli inizi di un percorso difficile, in Labour \& Law Issues, 4, 1, 2018, IV;

Lazzari C., Alla ricerca di tutele per $i$ gig-workers, fra supplenza giurisprudenziale, regolazione sociale e tentativi di normazione eteronoma, in Argomenti di Diritto del Lavoro, 3, 2019, 510;

Lobel O., The Law of the Platform, in Minnesota Law Review, 101, 2016, 87;

Loi P., Il lavoro nella gig economy nella prospettiva del rischio, in Rivista Giuridica del Lavoro, I, 2, 2017 , 259;

Lunardon F., Le reti d'impresa e le piattaforme digitali della sharing economy, in Argomenti di Diritto del Lavoro, 2, 2018, 375; 
Maio V., Il lavoro per le piattaforme digitali tra qualificazione del rapporto e tutele, in Argomenti di Diritto del Lavoro, 3, 2018, 118;

Martelloni F., Individuale e collettivo: quando i diritti dei lavoratori digitali corrono su due ruote, in Labour \& Law Issues, 1, 2018, 1;

Menegatti E., On-Demand Workers by Application: autonomia o subordinazione?, in Zilio Grandi G., Biasi M. (eds.), Commentario Breve allo Statuto del Lavoro Autonomo e del Lavoro Agile, Cedam, 2018, 93;

Nogler L., The concept of «subordination» in European and Comparative Law, Università degli Studi di Trento, 2009;

Occhino A., Nuove soggettività e nuove rappresentanze del lavoro nell'economia digitale, in Labor, 1, 2019, 39;

Papa V., Post-industriale o pre-moderno? Economia digitale e lavoratori on-demand: nuovi paradigmi organizzativi e vecchie esigenze di tutela, in Diritto delle Relazioni Industriali, 3, 2018, 729;

Persiani M., Contratto di lavoro e organizzazione, Cedam, 1966;

Perulli A., Lavoro e tecnica al tempo di Uber, in Rivista Giuridica del Lavoro, 2017, 2, I, 195;

Prassl J., Humans as a Service. The Promise and Perils of Work in the Gig Economy, Oxford University Press, 2018;

Razzolini O., The Need to Go Beyond The Contract: "Economic" and "Bureaucratic" Dependence in Personal Work Relations, in Comparative Labor Law \& Policy Journal, 31, 1, 2010, 267;

Recchia G.A., Alone in the crowd? La rappresentanza e l'azione collettiva ai tempi della sharing economy, in Rivista Giuridica del Lavoro, 1, 2018, 141;

Rogers B., Employment Rights in the Platform Economy: Getting Back to Basics, in Harvard Law \& Policy Review, 10, 2016, 479;

Romagnoli U., Se l'amore per la specie fa perdere di vista il genere (a proposito del caso Foodora), in Diritti Lavori Mercati, 1, 2018, 193;

Sachs B., Looks like the gig is up for Uber in California, in onlabor, may 1st 2018

Santoro Passarelli G., Sul nomen juris e le possibili tutele del rapporto di lavoro dei riders, in giustiziacivile.com, 30 aprile 2019;

Schubert C., Hütt M.-T., Economy-on-demand and the fairness of algorithms, in European Labour Law Journal, 10, 1, 2019, 3;
Secunda
P.,
Uber
Retirement,
2017 ,

https://papers.ssrn.com/sol3/papers.cfm?abstract id=2894566;

Signorini E., Il diritto del lavoro nell'economia digitale, Giappichelli, 2018;

Spinelli C., Tecnologie digitali e lavoro agile, Cacucci, 2018;

Stone K.V.W., From Widgets to Digits. Employment Regulation for the Changing Workplace, Cambridge University Press, 2004;

Todolì-Signes A., The End of Subordinate Worker? The On-Demand Economy, the Gig Economy, and the Need for Protection of Crowdworkers, in International Journal of Comparative Labour Law \& Industrial Relations, 2, 2017, 241;

Tomassetti J., From Hierarchies to Markets: FedEx Drivers and the Work Contract as Institutional Marker, in Lewis \& Clark Law Review, 19, 4, 2015, 1083;

Torsello L., I lavoro dei riders. L'iniziativa di legge nella Regione Lażio, in Diritti regionali. Rivista di diritto delle autonomie territoriali, 3, 2018, 2; 
Treu T., Rimedi, tutele e fattispecie: riflessioni a partire dai lavoratori della Gig economy, in Lavoro e Diritto, 3/4, 2017, 367;

Tullini P., Le collaborazioni etero-organizzate dei riders: quali tutele applicabili?, in Lavoro Diritti Europa, 1, 2019, 1;

Tullini P., Quali regole per il lavoratore-utente del web? Scambio economico e tutele, in Tullini P., Web e lavoro. Profili evolutivi e di tutela, Giappichelli, 2017, 141;

Voza R., Il lavoro e le piattaforme digitali: the same old story?, in WP C.S.D.L.E. "Massimo D'Antona".IT, 36/2017;

Voza R., Nuove sfide per il welfare: la tutela del lavoro nella gig economy, in Rivista del Diritto della Sicurezza Sociale, 4, 2018, 657;

Weiss M., Re-Inventing Labour Law?, in Davidov G., Langille B. (eds.), The Idea of Labour Law, Oxford University Press, 2011, 43.

Copyright (C) 2019 Marco Biasi. This article is released under a Creative Commons Attribution 4.0 International License 